Research Article

\title{
Preliminary Study of Actinomycetes as Potential Biocatalyst in Biodiesel Production Through Microbial Lipase Activity
}

\author{
Aidha Zulaika ${ }^{1 *}$, Sari Sekar Ningrum ${ }^{1,2}$, Dody Guntama² \\ ${ }^{1}$ Environmental Engineering Program, Faculty of Health Science and Technology, Binawan University, Jl. \\ Kalibata Raya-Dewi Sartika no. 24-26, Jakarta Timur, Indonesia \\ ${ }^{2}$ Chemical Engineering Program, Faculty of Industrial Technology, Jayabaya University. Jl. Raya Bogor. \\ Km28,8 Cimanggis, Depok, Indonesia 16052 \\ * Corresponding Author, email: zulaikakumala1727@gmail.com \\ (c) (1) ()
}

\begin{abstract}
Biocatalysts are biological substances that act as an accelerator of chemical reactions without causing influence on the living organism chemically. Biocatalysts based on renewable sources, biodegradable, tolerance to $\mathrm{pH}$ and temperature, and high selectivity to stereochemistry substrates and products. The utilization of biocatalyst is environmentally friendly and effective in production costs. This research aimed to determine the potential of actinomycetes as a biocatalyst in biodiesel production. This research method isolation and identification of actinomycetes isolates, conducting lipase activity test to determining lipase enzyme production of actinomycetes isolates. The data analysis in microbial identification was conducted by molecular identification by Gene bank through Basic Local Alignment Search Tool (BLAST). The lipase activity of actinomycetes analyzing by the value of lipase rate of test microbes. Based on chemical analysis of lipase activity, this research results show that actinomycetes $\mathrm{T}_{1} \mathrm{~A}$ has the highest lipase activity by $14.4640 \mathrm{mU} / \mathrm{g}$. Based on molecular identification analysis, actinomycetes T1A was identified as Streptomyces sp., 99\% similar to Streptomyces phaeochromogenes.
\end{abstract}

Keywords: Biocatalyst; biodiesel; lipase; streptomyces phaeochromogenes; BLAST

\section{Introduction}

Energy in Indonesia has suffered an energy crisis. For the last years, Indonesia has been imported fossil fuels to fulfill society's needs which no longer fed by national production. The government increases domestic fuel production by exploring and developing various types of national energy resources to achieve Indonesia's energy resilience and independence. One of the efforts is the development of new renewable energy. Based on the geographic condition of Indonesia, which are situated in equator line and as a tropical country, It has an enormous of variable renewable energy potential that spread out across the country, including solar energy sources, water energy and micro-hydro, wind energy sources, geothermal energy sources, ocean wave energy sources, biomass energy sources, and waste to energy (Saefulhak et al., 2017). In sustainable development, exploration and energy consumption of renewable energy has the potential for efficiency and energy conservation fulfilling reasonable and clean energy goals. In addition to that, the exploration, development, and consumption variety of national renewable energy potential will help achieve Indonesia's resilience and independence energy. 
One of the favorite energy exploration and development are biomass energy resources, in which organic material or substances from organisms produce energy. Because of rivalry in utilization, biomass energy resources are shifting in waste or non-edible biomass utilization for energy production. Biomass energy resource exploration converts biomass into bioethanol, bio solar, biodiesel, biogas, and other derivative products.

Biodiesel, which refers to fatty acid methyl ester (FAME), is alternative energy consisting of longchain fatty acid esters by transesterification process, which converts fatty acids derived from vegetable oil, animal fat, or recycled waste industrial production into other forms of liquid fuels. Biodiesel based on sources type divided into 3 classifications, in which the first generation are production based on vegetable oil. In contrast, second-generation is animal fat oils, and recently microbial sources and waste biomass are third generations developing to optimize efficiency and be environmentally friendly. The physical characteristic of biodiesel depends on the structure of each fatty ester of raw material. This condition influences biodiesel product characteristics such as ignition quality, the heat of combustion, exhaust emissions, oxidative stability, cold flow, viscosity, density, and lubricity (Sharma et al., 2019). Acid-base catalysts generally assist biodiesel production (Zheng L et al., 2012; Rizwanul et al., 2020) or biocatalyst and lipase-based microbes utilization (Nguyen HC. et al., 2017; Zheng L et al., 2012).

Biocatalysts are biological substances also defined as enzymes which are act as accelerator of chemical reactions without causing influence on the living organism chemically (Rizwanul et al., 2020; Ondul, et al., 2015; Fathurrahman, 2019). Biocatalysts or enzymatic process in comparison with chemical process have many benefits such as more efficient in catalytic reaction, biodegradable, tolerance to $\mathrm{pH}$ and temperature, high selectivity to stereochemistry substrates and products, efficient in production costs and environmental friendly (Guldhe, et al., 2015). Thus, biocatalyst become preferable choice of technique in producing of variety industrial substances (Anteneh and Franco, 2019; Jemli et al., 2016).

Lipases are serine hydrolases known as triacylglycerol acetylhydrolase. It is also a lipid-breaking enzyme, one of the enzymes that have high activity in various chemical reactions, including hydrolysis, esterification, and transesterification due to its ability in hydrolyzed carboxyl esters of long-chain acylglycerol (Wahyuningsih et al., 2015; Casas-Godoy et al., 2018). Lipase mainly originated from microbialproducing lipase, but lipase is another resource in many organisms, including plants, animals, and waste. This variety of sources also give variation on lipase structure, structurally lipase are differentiated by characterizing conserved alpha/beta hydrolase fold, which is one of the most comprehensive groups of enzymes in relation structurally with various catalytic abilities, lipase also distinguished by catalytic triad presence, which is a set of three amino acids usually found in enzyme active region, lastly the company of disulfide bridges that give the enzyme stability and essential in catalytic activity also in consideration (Casas-Godoy et al., 2018; Lenfant et al., 2013).

Extracellular and intracellular lipases are commonly charged at the enzymatic biodiesel process. Extracellular lipases are enzymes derived from microorganisms after isolation and purification before, whereas intracellular lipases, in contrast with extracellular lipases, are enzymes within the cell or in cell walls producing enzymes (Gog et al., 2012; Andualema \& Gessesse, 2012). Intracellular lipases are more favorable than extracellular lipase based on technical and efficiency aspects. Intracellular lipases have to go through enzymes extraction and purification, which are costly, technical complexion procedures, and timeconsuming, whereas Intracellular lipase is not (Rizwanul et al., 2020). Intracellular lipase usually used by whole-cell lipase producing microorganism technology that utilizes natural lipase production process, in addition to that whole-cell lipase producing microorganisms can be reused or continuously applied (Xiao et al., 2011; Fukuda et al., 2008; Aguieiras et al., 2016; Lee et al., 2010; Chen et al., 2011; Sharma et al., 2019) using immobilized cell technology which is immobilized microbial-derived enzymes or whole-cell microorganism using various technology (Aguieiras et al., 2016; Vargas et al., 2018). Assisted cofactors generation, non-activated carbon atom selective hydroxylation, high region-stereo selectivity, numerous options of cascades process in substrate biotransformation (De Carvalho, 2017). 
Microorganism-producing lipase is studied and has recently become a novel enzyme production focus due to its successful application in widely industrial sectors. A wide range of bacteria, fungi, and other microorganisms produce hundreds of lipase enzymes (Chandra et al., 2020; Andualema \& Gessesse, 2012). Actinobacteria or actinomycetes are lipase-producing microbes (Fathurrahman, A.T., 2019). Actinomycetes or actinobacteria are a filamentous gram-positive bacteria phylum, abundantly in most soil, decomposition of organic material, produce a wide range of chemical products successfully used in a variation of industrial application (Prakash et al., 2013; Vaijayanthi et al., 2016). Of over 22.0oo reported biobased active substances of microbial metabolites, $45 \%$ are derived from actinobacteria, of which threefourths of the total are produced from Streptomyces sp. (Anteneh et al., 2019; Barka et al., 2015). Actinomycetes found in extreme habitats produce novel enzymes with huge commercial industry potential (Mukhtar et al., 2017), Actinobacteria or actinomycetes also in recent robust exploration and development in bioenergy sectors(El-Sheekh et al., 2017; Hama et al., 2018; Sasso et al., 2016; Ayaz et al., 2015; Lan et al., 2016).

\section{Methods}

\subsection{Sample Collection}

Soil samples were collected from five different succulent plants rhizospheres (Figure. 1) which are Euphorbia sp. 1, Echinocactus grusonii, Deuterocohnia sp., Euphorbia sp. 2, and Escheveria sp. in about 8 to $10 \mathrm{~cm}$ depth, collected into sterile plastic bags and stored in refrigerator at $4{ }^{\circ} \mathrm{C}$ before isolation process (Zulaika et al., 2021).

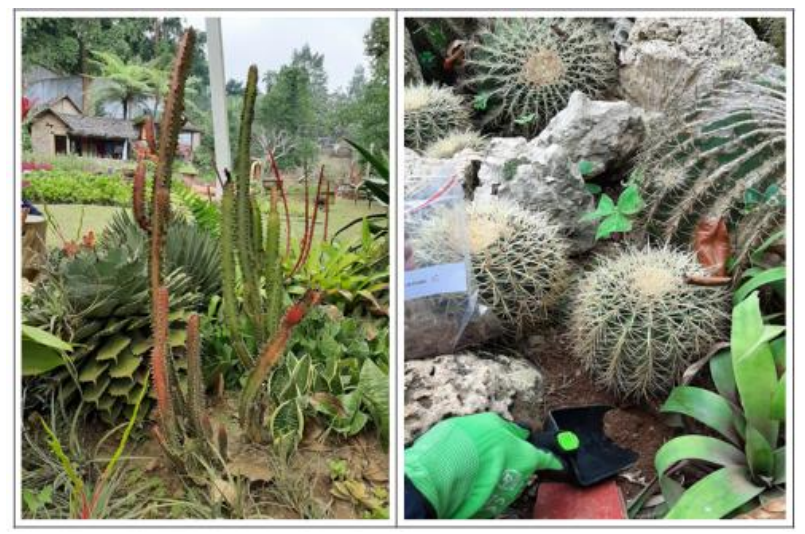

Figure 1. Sample collection from different succulent plants rhizospheres.

\subsection{Isolation of Actinomycetes}

Actinomycetes were isolated by the serial dilution method. Weights of 10 grams of each soil sample were diluted with phosphate buffer to seven-fold dilution. The last five dilutions plated by pour plate method on $\mathrm{HV}$ agar (Humic acid-Vitamin agar: $1 \mathrm{~g}$ humic acid; $0.02 \mathrm{~g} \mathrm{CaCO}$; $0.01 \mathrm{~g} \mathrm{FeSO} 4$. $7 \mathrm{H}_{2} \mathrm{O}$; $1.71 \mathrm{~g} \mathrm{KCl}$; o, $05 \mathrm{~g}$ $\mathrm{MgSO}_{4.7} \mathrm{H}_{2} \mathrm{O}$; $0.5 \mathrm{~g} \mathrm{Na} \mathrm{HPO}_{4} ; 50$ g siklohesamida; $20 \mathrm{~g}$ agar) and Potato Dextrose Agar (PDA). Then incubated at $25^{\circ} \mathrm{C}$ for 4 to 14 days (Saraswati et al., 2007).

\subsection{Actinomycetes Lipase Activity Preliminary Screening}

5 out of 10 isolates are randomly selected for lipase activity preliminary screening. The propagation of actinomycetes culture in medium GDP for lipase analysis and actinomycetes selected are grown in $50 \mathrm{~mL}$ medium GDP (OXOID CM 129), then incubated in 300C for 5-7 days.

The determining of Lipase activity was tested by a method based on the increased levels of free fatty acids in the sample (Palilingan et al., 2013). $3 \mathrm{~g}$ of CPO and $1 \mathrm{~g}$ of polyvinyl alcohol are dissolved in a 40 $\mathrm{mL}$ buffer phosphate-citrate $\mathrm{pH} 5$ and supplemented with a $1 \mathrm{~mL}$ solution of the enzyme. The sample was incubated at room temperature $\left(25-30^{\circ} \mathrm{C}\right)$ for 30 minutes. The reaction is stopped by adding $20 \mathrm{~mL}$ of acetone mixture: ethanol $(1: 1 \mathrm{v} / \mathrm{v})$. Then the sample was titrated using $\mathrm{NaOH} 1 \mathrm{~N}$ using the phenolphthalein 
indicator until the endpoint was pink. Blanco, the same procedure is carried out without treating enzyme addition (Tri-Panji et al., 2019). Free fatty acid levels are calculated using the following equation:

$$
\text { Free fatty acid levels }=\frac{V \mathrm{NaOH}(\mathrm{mL}) \times[\mathrm{NaOH}](\mathrm{M})}{\text { Weight Sample }}
$$

Lipase activity is calculated using the following equation:

$$
\begin{aligned}
\text { Lipase Activity } & =\frac{\text { Free fatty acid levels }(\text { Blnco Sample })}{\text { Incubation Time }(\text { minutes })} \\
& =\frac{V \mathrm{NaOH}(\mathrm{mL}) \times[\mathrm{NaOH}](\mathrm{M})(\text { Sample }- \text { Blanco })}{\text { Weight Sample }(\text { g) }) \text { Incubation Time } \text { (minutes })}
\end{aligned}
$$

\subsection{Actinomycetes Identification}

Selected actinomycetes isolates were identified by PCR and sequencing method (Gene aid). Identification based on gene encoding $16 \mathrm{~S}$ ribosomal RNA, which is the most frequently used in bacterial and archaea identification due to slow changes of gene evolution, exist almost in all bacterial genome and contain around 150obp with various specific functional domain (Michael Janda and Abbott, 2019). DNA sequence fragments obtained were analyzed in Gene bank through the BLAST method, whereas specific similarity regions in the collected sequence were located and compared to find matches in the existing gene database then statistically calculated insignificance (Bazinet et al., 2018; Ladunga, 2017; Wijayanti et al., 2020).

\section{Result and Discussion}

3.1. Isolation of Actinomycetes

Succulents are plants commonly lived in extremes conditions, usually drought regions with water scarcity to the nonexistence of water as in arid and semi-arid areas. They developed morphologically and physiologically structure and condition to adapt to extreme habitat conditions for survival. A recent study indicates succulent plants survival and adaptation could derive from plants and microorganisms associations (Nessner Kavamura et al., 2013; Fonseca-García et al., 2016; Karray et al., 2020; De Lyra et al., 2021; Bezerra et al., 2017).

Soil ecosystem has many influential and important components, one of its are soil microorganisms which naturally act as a degrader in various processes of organic material degradation, charge in biotransformation various soil chemical substances and other elements, take the role in nutrients distribution and recycling process essential in animals, plants, other organisms growth, and development (Zulaika et al., 2021). Soil microorganisms exist in various groups microorganisms, commonly found in bacteria, fungi, actinomycetes or actinobacteria, algae, and protozoa groups (Susilawati et al., 2013). Various groups of bacteria, fungi, and actinomycetes or actinobacteria included as an endophytic organism which describes mutualism association of plants and microorganism in the effect of microorganism colonization in root plant it helps plants growth optimally by assisting absorbing essential nutrients from the soil and as plant immune defense by secreted various active secondary metabolites. Contextually, Rhizhosphere describes soil microorganisms and higher plants association in root systems. It concludes of plant root area and soil surface layer of rhizospheres in which high microbiological activity commonly occurs (Baliyarsingh et al., 2017). The soil and vegetation condition greatly influenced rhizosphere microorganism community diversity and its movement (Zulaika et al., 2021).

Actinomycetes are colonized in various types of habitats. In the soil ecosystem, Actinomycetes are one of the rhizosphere microorganism communities and other microorganisms, including bacteria, fungi, algae, and protozoa. The environmental and also physicochemical conditions, including soil type and condition, organic substances, cultivation, and land use, habitat geographically, temperature, $\mathrm{pH}$, salinity, aeration, and moisture soil affected the abundance and variation of actinomycetes existence in any particular soil ecosystem (Arifuzzaman et al., 2010; Zanane et al., 2018). 
Actinomycetes were present in all soil samples, the number of actinomycetes isolates abundantly varied in each soil sample. Plate culture dilution ranging from 104-107, based on colony actinomycetes grow on each plate vary in size and appearance and even some culture visualized to have the antimicrobial ability (Figure. 2). This shows rhizosphere is a natural habitat for actinomycetes. It has rich nutrition for the actinomycete's growth and development. Actinomycetes originated from rhizosphere reported to have antimicrobial compounds (Muleta \& Assefa, 2018; Apsari et al., 2019) and potentially as alternative biofertilizer for growth promotion and various agro-active compounds (Anwar et al. 2016) as before explained that actinomycetes found in extreme habitats (as in succulents plant in drought habitat) produce novel enzymes with huge commercial industry potential (Mukhtar et al., 2017) that could be explored for production.
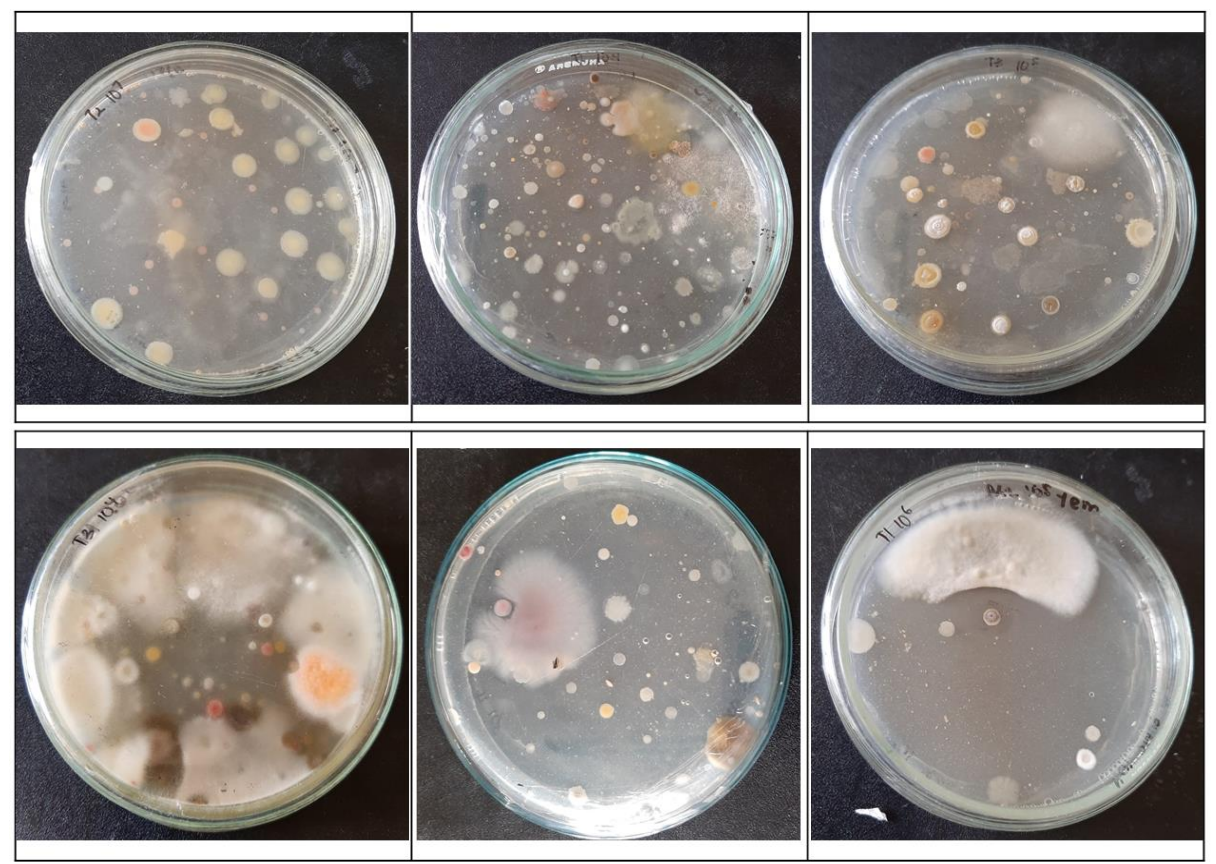

Figure 2. Abundant of various actinomycetes culture plate in PDA media, in three plate culture in the bottom line, some colony of actinomycetes expressed clearly antimicrobial ability.

5 colony cultures were isolated to further study in the lipase activity test. The selection of actinomycetes was based on size, Aerial hyphae color, and antimicrobial activity. Those cultures are actinomycetes $\mathrm{T}_{1} \mathrm{~A}, \mathrm{~T}_{1} \mathrm{~B}, \mathrm{~T}_{3} \mathrm{D}, \mathrm{T}_{3} \mathrm{C}$, and $\mathrm{T}_{5} \mathrm{~A}$ (Figure 3 ). Based on the visual appearance of colony culture on aerial hyphae color, $\mathrm{T}_{1} \mathrm{~A}$ isolates have a reddish-brown colony appearance, $\mathrm{T}_{1} \mathrm{~B}$ isolated culture has a sly red colony appearance with a bulge in the middle of the colony. $\mathrm{T}_{3} \mathrm{D}$ remote colony culture has a white colony color with a bump structured in the middle of the settlement. $\mathrm{T}_{3} \mathrm{C}$ isolated colony culture has an appearance that resembles $\mathrm{T}_{3} \mathrm{D}$ isolate colony culture, and however single colony has a flat side. Meanwhile, the $\mathrm{T}_{5} \mathrm{~A}$ colony culture has a whitish colony color with a structured, spotted settlement with a distinctive surface of reddish-brown bacteria. 


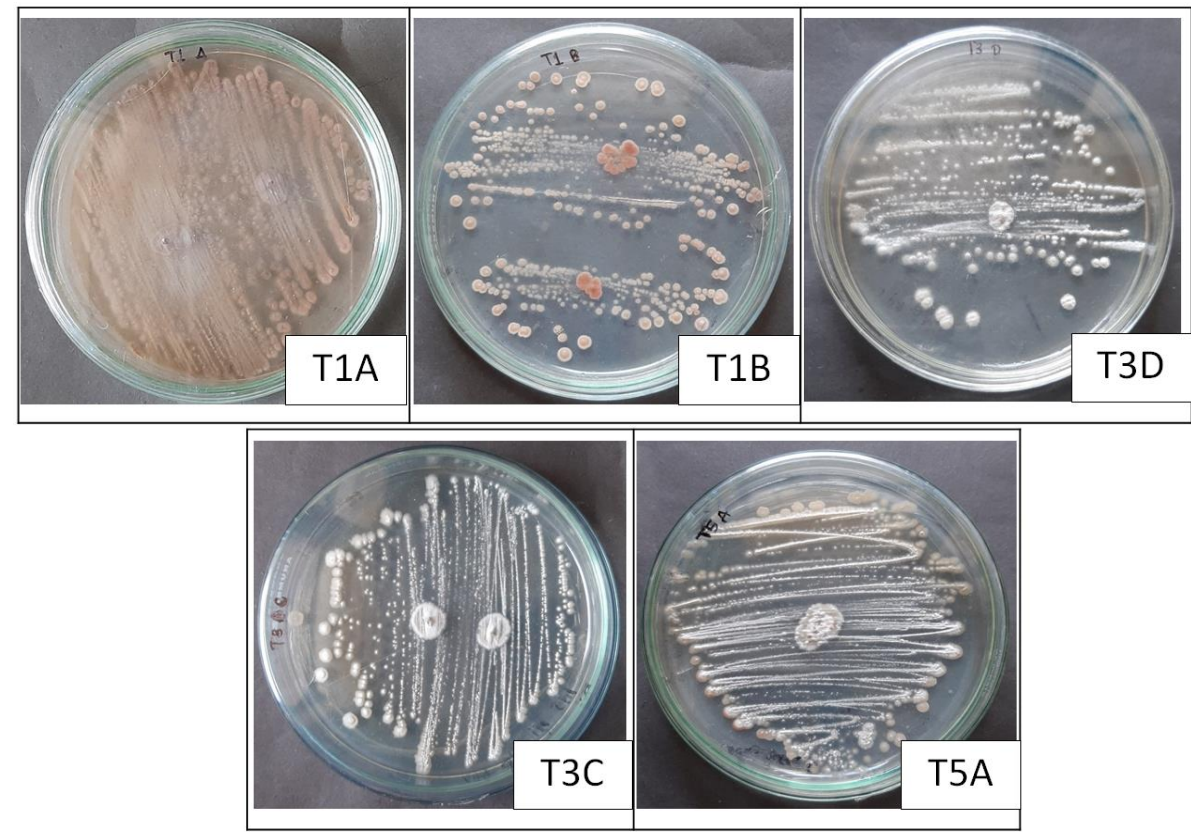

Figure 3. Five selected pure culture of succulents rhizhosphere isolated actinomycetes.

\subsection{Lipase Activity Test of Actinomycetes}

Lipase enzymes are usually derived from many organisms and take part in the metabolism of oils and fats. Lipases take charge of the lipid's metabolism, depositions, and transfers. It also has outstanding catalytic ability and stability in no aqueous media, variety class in region-selectivity, and enantiomerselectivity has successfully and widely applied in many applications of organic synthesis and various reactions, including alcohol lysis, amino lysis, acid lysis, and esterification or transesterification (Gog et al., 2012).

Mainly lipases produced are derived from microbes. Before being selected for lipase production, Lipase microorganisms were isolated and tested for lipolysis ability. Various factors are influential in Lipase production. Several nutrients, mixture ratio, metal ions, $\mathrm{pH}$, agitation, temperature, water content, dissolved oxygen, and timely reaction. The methods used for lipase purification are generally stratified by applying ultrafiltration or ammonium sulfate precipitation to the concentration of culture media, at a later stage with further purification using either one of the chromatography techniques, membrane processes, gel filtration, or immunological techniques of purification. (Luna, $C$ et al., 2016).

Microbial lipase selection In biodiesel conversion becomes an essential step because of lipase's importance in hydrolysis reactions. Lipase is charged on carboxyl ester bonds in triglycerides when producing fatty acid and glycerol. The region-selectivity of lipases is classified based on hydrolyze ester bonds positions. In addition, the substrate specificity of lipases enables them to differentiate various forms of acyl chains. (Luna, C et al., 2016).

This Lipase Activity Test is analyzed as a preliminary study in determining lipase production in actinomycetes. In biodiesel conversion, lipase is a crucial enzyme in breaking down fatty acid contained in biomass into fatty acid Methyl Ester. Based on the lipase rate, mostly actinomycetes have quite high lipase rate on all isolate exclude actinomycetes $\mathrm{T}_{3} \mathrm{C}$ only $7.6840 \mathrm{mU} / \mathrm{ml}$. Whereas the other reach above 10.000 $\mathrm{mU} / \mathrm{g}$. Actinomycetes T1A is the highest lipase activity rate by $14.4640 \mathrm{mU} / \mathrm{g}$ (Table $\mathbf{1}$ ). 

Activity.

J. Presipitasi, Vol 18 No 3: 512-523

Table 1. Lipase activity rate

\begin{tabular}{lcc}
\hline & \multicolumn{2}{c}{ Lipase Activity of Actinomycetes } \\
\hline No & Code Culture & Lipase Enzyme rate $(\mathbf{m U} / \mathbf{g})$ \\
1 & Actinomycetes $\mathrm{T}_{1} \mathrm{~A}$ & 14.4640 \\
2 & Actinomycetes $\mathrm{T}_{1} \mathrm{~B}$ & 12.6560 \\
3 & Actinomycetes $\mathrm{T}_{3} \mathrm{D}$ & 14.0120 \\
4 & Actinomycetes $\mathrm{T}_{3} \mathrm{C}$ & 7.6840 \\
5 & Actinomycetes $\mathrm{T}_{5} \mathrm{~A}$ & 11.7520 \\
\hline
\end{tabular}

Based on prior culture, actinomycetes T1A shows un-doubly metabolites ability by clearly visible antimicrobial activity (Figure 4). Microbes with high metabolite production tend to have various agroactive compounds such as protease, lignocellulose, lipase, etc. (Anwar et al., 2016).
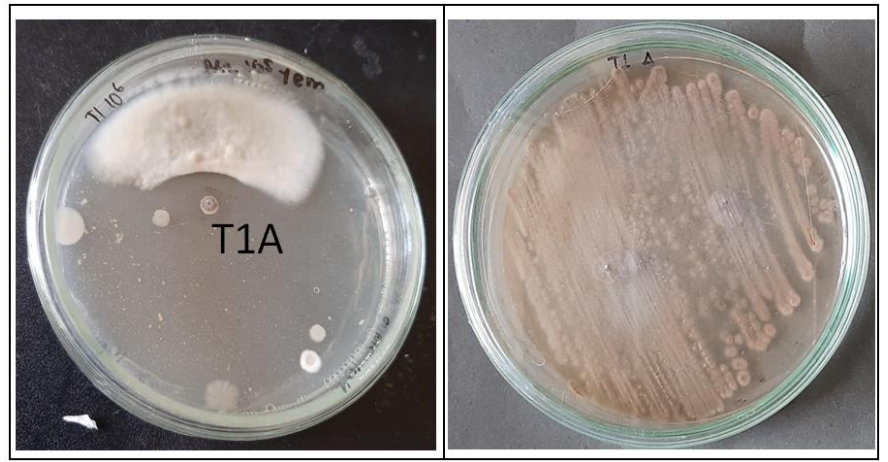

Figure 4. Actinomycetes T1A antimicrobial activity

\subsection{Identification of Actinomycetes}

Actinomycetes $\mathrm{T} 1 \mathrm{~A}$ as the highest lipase activity rate will be studied further in the biodiesel production test. Therefore identification is needed. Culture identification of actinomycetes T1A isolates has a reddish-brown colony appearance. Whereas molecular identification by PCR and sequencing method (Gene aid) based on gene encoding $16 \mathrm{~S}$ ribosomal RNA, DNA sequence fragment obtained were analyzed in Gene bank through BLAST method, resulting in actinomycetes TiA identified as Streptomyces sp. which is 99\% similar to Streptomyces phaeochromogenes (Wijayanti et al., 2020). BLAST result shows in Figure 5.

\begin{tabular}{|c|c|c|c|c|c|c|c|c|c|}
\hline & Description & Common Name & $\begin{array}{l}\text { Max } \\
\text { Score } \\
\square\end{array}$ & $\begin{array}{l}\text { Total } \\
\text { Score } \\
\nabla\end{array}$ & $\begin{array}{l}\text { Query } \\
\text { Cover } \\
\nabla\end{array}$ & 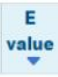 & $\begin{array}{l}\text { Per. } \\
\text { Ident } \\
\nabla\end{array}$ & Acc. Len & Accession \\
\hline$\nabla$ & Streptomyces sp. strain MB106 16S ribosomal RNA gene, partial sequence & Streptomyces sp. & 2514 & 2514 & $100 \%$ & 0.0 & $99.14 \%$ & 1467 & MH699222.1 \\
\hline$\nabla$ & $\underline{\text { Streptomyces sp. strain T1317-0316 16S ribosomal RNA gene. partial sequence }}$ & Streptomyces sp & 2514 & 2514 & $100 \%$ & 0.0 & $99.14 \%$ & 1478 & MF962865.1 \\
\hline$\nabla$ & $\underline{\text { Streptomyces phaeochromogenes strain HBUM174705 } 16 \text { S ribosomal RNA gene, partial sequence }}$ & Streptomyces... & 2514 & 2514 & $100 \%$ & 0.0 & $99.14 \%$ & 1433 & $\underline{\text { FJ486378.1 }}$ \\
\hline 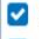 & Streptomyces phaeochromogenes strain NRRL B-2123 16 S ribosomal RNA gene, partial sequence & Streptomyces.... & 2514 & 2514 & $100 \%$ & 0.0 & $99.14 \%$ & 1489 & EU594477.1 \\
\hline 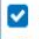 & $\underline{\text { Streptomyces phaeochromogenes strain NRRL B-1517 16S ribosomal RNA gene, partial sequence }}$ & myces.... & 2514 & 2514 & $100 \%$ & 0.0 & $99.14 \%$ & 1466 & EU594474.1 \\
\hline 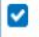 & $\underline{\text { Streptomyces melanogenes strain NBRC } 1289016 \text { S ribosomal RNA partial sequence }}$ & Streptomyces.... & 2514 & 2514 & $100 \%$ & 0.0 & $99.14 \%$ & 1475 & $\underline{N R \_0410891}$ \\
\hline$\nabla$ & 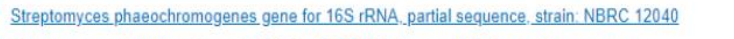 & Streptomyces... & 2514 & 2514 & $100 \%$ & 0.0 & $99.14 \%$ & 1450 & AB184057.1 \\
\hline 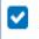 & $\underline{\text { Streptomyces noboritoensis strain NBRC } 1306516 \mathrm{~S} \text { ribosomal RNA.partial sequence }}$ & $\underline{\text { Streptomyces }} . .$. & 2510 & 2510 & $100 \%$ & 0.0 & $99.06 \%$ & 1477 & $\underline{\text { NR_0 } 041107.1}$ \\
\hline च & Streptomyces melanogenes strain NRRL B-2072 16S ribosomal RNA partial sequence & Streptomyces... & 2508 & 2508 & $100 \%$ & 0.0 & $99.07 \%$ & 1528 & NR_115783.1 \\
\hline 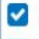 & Streptomyces noboritoensis strain DB38 16 S ribosomal RNA gene, partial sequence & Streptomyces.... & 2503 & 2503 & $100 \%$ & 0.0 & $98.99 \%$ & 1477 & KY056174.1 \\
\hline 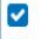 & Streptomyces noboritoensis strain CSSP69516S ribosomal RNA partial sequence & Streptomyces... & 2492 & 2492 & $100 \%$ & 10 & $98.85 \%$ & 1421 & NR_115420.1 \\
\hline ఐ & Streptomyces noboritoensis strain JCM 4557 16S ribosomal RNA gene, partial sequence & Streptomyces... & 2490 & 2490 & $100 \%$ & 0.0 & $98.78 \%$ & 1401 & MT760572.1 \\
\hline 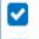 & Streptomyces phaeochromogenes strain MJM4365 165 ribosomal RNA gene, partial sequence & Streptomyces... & 2470 & 2470 & $100 \%$ & 0.0 & $98.56 \%$ & 1427 & FJ799175.1 \\
\hline$\nabla$ & Streptomyces olivochromogenes gene for 16 S rRNA, partial sequence, strain: NBRC 3404 & Streptomyces... & 2459 & 2459 & $100 \%$ & 0.0 & $98.42 \%$ & 1481 & AB184761.2 \\
\hline & $\underline{\text { Streptomyces olivochromogenes strain HBUM174717 16S ribosomal RNA gene, partial sequence }}$ & Streptomyces... & 2459 & 2459 & $100 \%$ & 0.0 & $98.42 \%$ & 1440 & EU841608 \\
\hline
\end{tabular}




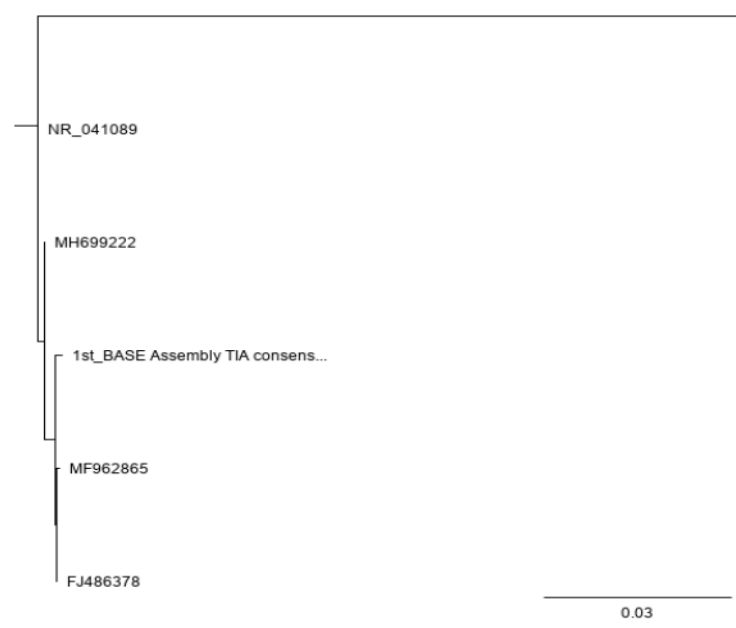

Figure 5. T1A was identified as streptomyces phaeochromogenes through BLAST Method. Above: BLAST result shows sequences producing significant alignment matches in databased. Below: Phylogenetic tree of the T1A sample with other closely related strains.

In a recent study, Streptomyces sp. globally reported successfully used in biodiesel production using lipase activity assisting in biodiesel conversion. Research by El-Sheekh et al. (2017) co-culture actinomycetes and microalgae in biodiesel production by the batch system resulting in $93 \%$ of Streptomyces fatty acids being successfully converted to biodiesel. Research by Cho, 2012, as lipase enzyme derived from Streptomyces sp. $\mathrm{CS}_{32} 6$ was extracted for biodiesel production, which are new substances than existing lipases. Research by Ugur et al. (2014) conducted the isolation and characterization of lipase enzymes derived from 300 Streptomyces isolates, producing high lipolytic activity in high-temperature reactions and organic solvents through organic solvents transesterification. Recently reported brand new immobilized lipase derives from marine Streptomyces sp., applied in biodiesel production in reaction with methanol at the non-solvent process (Yuan et al., 2016; Wang et al., 2017).

As in Indonesia, Streptomyces sp. is commonly used in producing chemical medicine, antibiotics, anticancer ability, and any other health-related functional (Rahayu, 2011; Chasanah et al., 2012; Krismawati et al., 2015; Nuzulia et al., 2021). Scientific records of Streptomyces sp. utilization in biodiesel production in Indonesia have not yet been seen so far. However, globally has been a success, as explained before. As a comparison in Tabel 2 will be shown biodiesel yield properties of successful utilization of Streptomyces $s p$. in biodiesel production study with yield properties values based on several American Society for Testing and Materials (ASTM) standards for liquid fuel such as ASTM: D-2638, ASTM 1310, ASTM 240, etc. (ElSheekh et al., 2017) and National Standard of Indonesia (SNI) 7182:2015 for Biodiesel. Based on these explanations, therefore, Streptomyces sp. has a high potential to be utilized in biodiesel production as a biocatalyst. Especially in Indonesia, where Streptomyces sp. utilization in biodiesel production is rare.

Table 2. Biodiesel yield properties based on research study (El-Sheekh, et al., 2017), ASTM and SNI 7182:2015

\begin{tabular}{lccc}
\hline & \multicolumn{3}{c}{ Biodiesel Yield Values } \\
\hline Properties & Research & ASTM $^{*}$ & SNI \\
\hline Density at $15.56^{\circ} \mathrm{C}$ & 0.8655 & $<0.95$ & $0.850-0.890 \mathrm{~g} / \mathrm{cm}^{3}\left(40{ }^{\circ} \mathrm{C}\right)$ \\
Specific Gravity & 0.8664 & $<0.92$ & - \\
API Gravity at $60^{\circ} \mathrm{F}$ & 31.82 & $20-40$ & - \\
Total Acid No. $(\mathrm{mg} \mathrm{KOH} / \mathrm{g})$ & 1.298 & $<0.5$ & 0.5 Maximal \\
Kinetic Viscosity at $40^{\circ} \mathrm{C}\left(\mathrm{mm}^{2} / \mathrm{s}\right)$ & 6.92 & $<7.2$ & $2.3-6.0$ \\
Pour Point $\left({ }^{\circ} \mathrm{C}\right)$ & 21 & $8-25$ & - \\
Total Sculpture $(\%$ wt. $)$ & 0.74 & $<0.85$ & - \\
\hline
\end{tabular}


J. Presipitasi, Vol 18 No 3: 512-523

\begin{tabular}{lccc}
\hline & \multicolumn{3}{c}{ Biodiesel Yield Values } \\
\hline Properties & Research & ASTM & SNI \\
\hline Ash content $(\% \mathrm{wt})$. & 0.004 & $<0.02$ & 0.02 Maximal \\
Carbon Residue (\% wt.) & 7.2 & $5-15$ & 0.05 per real sample \\
& & & 0.3 per 10\% distillation waste \\
Gross Heating value (Kj/Kg) & 43426 & $<50600$ & - \\
Flash Point $\left({ }^{\circ} \mathrm{C}\right)$ & 96 & $90-130$ & 100 Minimum \\
Cetane No. & 38 & $<47$ & 51 Minimum \\
\hline
\end{tabular}

* Standard chemical and physical limits for row liquid fuels, with no cetane-processing additives according to American Society for Testing Materials

\section{Conclusions}

The present study suggests that actinomycetes derived from the rhizosphere of succulent plants are potentially applicable in biodiesel production based on lipase activity. Mainly Streptomyces has successfully utilized in biodiesel production study applying lipase enzyme.

\section{Acknowledgement}

Acknowledgments are primarily addressed to Research Technology- National Research and Innovation Agency (RISTEK-BRIN) has funded this research by PDP Research Grant. The Research Contract for the 2021 Fiscal Year Number: LLDIKTI research contract with Binawan University: 3538/LL3/KR/2021, Researcher research contract 012/LT/UBN.LPPM/VII/2021.

\section{References}

Aguieiras, E.C.G., D.S. Ribeiro, P.P. Couteiro, C.M.B. Bastos, D.S. de Queiroz, J.M. Parreira, M.A.P. Langone. 2016. Investigation of the reuse of immobilized lipases in biodiesel synthesis: influence of different solvents in lipase activity. Applied Biochemistry and Biotechnology. 179, pages 485-496.

Andualema, B., \& A. Gessesse. 2012. Microbial lipases and their industrial application: review. Biotechnology, 11 (3): 100-118.

Anteneh, Y.S., and C.M.M. Franco. 2019. Whole cell actinobacteria as biocatalysts. frontiers in microbiology, 10:(77).

Anwar, S., B. Ali, I, Sajid. 2016. Screening of rhizospheric actinomycetes for various in-vitro and in-vivo plant growth promoting (PGP) traits and for agroactive compounds. Frontiers in Microbiology, 7: 1334

Apsari, P.P., S. Budiarti, A.T. Wahyudi. 2019. Actinomycetes of rhizosphere soil producing antibacterial compounds against urinary tract infection bacteria. Biodiversitas Journal of Biological Diversity, 20 (5): 1259-1265.

Arifuzzaman, M., M.R. Khatun, H. Rahman. 2010. Isolation and screening of actinomycetes from sundarbans soil for antibacterial activity. African Journal of Biotechnology, 9(29): 4615-4619

Ayaz, B., A. Ugur, R. Boran. 2015. Purification and characterization of organic solvent-tolerant lipase from Streptomyces sp. OC119-7 for biodiesel production. Biocatalysis and Agricultural Biotechnology 4(1): 103-108.

Baliyarsingh, B., S.K. Nayak, B.B. Mishra. 2017. Soil microbial diversity: an eco physiological study and role in plant productivity. In K.U. Adhya T., B. Mishra, K. Annapurna, D. Verma. (Ed.), Advances in Soil Microbiology: Recent Trends and Future Prospects. Microorganisms for Sustainability. Springer.

Barka, E. A., P. Vatsa, L. Sanchez, N. Gaveau-Vaillant, C. Jacquard, J.P. Meier-Kolthoff, et al., 2015. Taxonomy, physiology, and natural products of actinobacteria. Microbiology and Molecular Biology Reviews, 80: 1-43.

Bazinet, A. L., B. D. Ondov, D.D. Sommer, S. Ratnayake. 2018. BLAST-based validation of metagenomic sequence assignments, 6: 4892 . 
Bezerra, J. D. P., Azevedo, J. L. de, C. M. Souza-Motta. 2017. Why study endophytic fungal community associated with cacti species?. Diversity and Benefits of Microorganisms from the Tropics, 21-35.

Casas-Godoy, L., F. Gasteazoro, S. Duquesne, F. Bordes, A. Marty, and G. Sandoval. 2018. Lipases: an overview. Georgina Sandoval (ed.), Lipases and Phospholipases: Methods and Protocols. Methods in Molecular Biology, vol. 1835.

Chandra, P., Enespa, R.Singh, P.K. Arora. 2020. Microbial lipases and their industrial applications: a comprehensive review. Microbial Cell Factories. 19(169).

Chasanah, E., N.M. Noor, Y. Risjani, A.S. Dewi. 2012. Antibacterial and antiocsidan activity extract of streptomyces sp. and exserohilum rostratum cultivated to three growth Medium. Jurnal Pascapanen dan Bioteknologi Kelautan dan Perikanan. 7(1).

Chen, H.C, H.Y Ju, T.T Wu, Y.C Liu, C.C Lee, C. Chang, Y.L Chung, C.J Shieh. 2011. Continuous production of lipase-catalyzed biodiesel in a packed-bed reactor: optimization and enzyme reuse study. Hindawi Publishing Corporation Journal of Biomedicine and Biotechnology.

Cho, S.S., D.J. Park, J.R. Simkhada, J.H. Hong, J.K. Sohng, O.H. Lee, J.C. Yoo. 2012. A neutral lipase applicable in biodiesel production from a newly isolated Streptomyces sp. CS 326 . Bioprocess and Biosystems Engineering. 35(1-2): 227-34.

de Carvalho, C. C. 2017. Whole cell biocatalysts: essential workers from Nature to the industry. Microbial Biotechnology. 10: 250-263.

De Lyra, M.D.C.C.P., R.G. Taketani, A.D. De Freitas, C.E.R.S.E. Silva, A.C.E.S. Mergulhão, M.L.R.B. Da Silva, J.E.L.S. Antunes, A.S.F. De Araújo, P.F. Giachetto. 2021. Structure and diversity of bacterial community in semiarid soils cultivated with prickly-pear cactus (Opuntia ficus-indica (1.) mill.). Anais Da Academia Brasileira de Ciencias, 93(3): 1-9.

El-Sheekh, M.M., N.G. Allam, S.A. Shabana, M.M. Azab. 2017. Efficiency of lipid accumulating Actinomycetes isolated from soil for biodiesel production: Comparative study with microalgae. Taylor, Francis online. 39(9).

Fathurrahman, A.T. 2019. Actinobacteria: potential novel source of biocatalyst. BioTrends, 10(1).

Fonseca-García, C., D. Coleman-Derr, E. Garrido, A. Visel, S.G. Tringe, L.P. Partida-Martínez. 2016. The Cacti microbiome: interplay between habitat-filtering and host-specificity. Frontiers in Microbiology, 7 .

Fukuda, H., S. Hama, S. Tamalampudi, H. Noda. 2008. Whole-cell biocatalysts for biodiesel fuel production. Trends in Biotechnology, 26(12).

Guldhe, A., B. Signgh, T. Mutanda, K. Permaul, F. Bux. 2015. Advances in synthesis of biodiesel via enzyme catalysis: novel and sustainable approaches. Renewable and Sustainable Energy Reviews 41(2015): 1447-1464

Gog, A., M. Roman, M. Tosa, C. Paizs, F.D. Irimie. 2012. Biodiesel production using enzymatic transesterification current state and perspectives. Renewable Energy, 39: (10-16).

Hama, S., H. Noda, A. Kondo. 2018. How lipase technology contributes to evolution of biodiesel production using multiple feedstocks. Current Opinion in Biotechnology. 50:57-64

Jemli, S., D. Ayadi-Zouari, H.B. Hlima, S. Bejar. 2016. Biocatalysts: application and engineering for industrial purposes, critical reviews in biotechnology, 36 (2): 246-58.

Karray, F., M. Gargouri, A. Chebaane, N. Mhiri, A. Mliki, S. Sayadi. 2020. Climatic aridity gradient modulates the diversity of the rhizosphere and endosphere bacterial microbiomes of opuntia ficusindica. Frontiers in Microbiology.

Krismawati, H., L. Sembiring, S. Wahyuono. 2015. Sreptomycetes producing antibiotic associated with rhizospher some mangrove species. PLASMA, 1(2): 59-70

Ladunga, I. 2017. Finding similar nucleotide sequences using network BLAST searches. current protocols in bioinformatics, $58: 3 \cdot 3 \cdot 1-3 \cdot 3 \cdot 25$. 
Lan, D., M. Qu, B. Yang, Y. Wang. 2016. Enhancing production of lipase MAS1 from marine streptomyces sp. strain in pichia pastoris by chaperones co-expression. Electronic Journal of Biotechnology, 22:62-67.

Lee, J.H., S.B Kim, C. Park, B. Tae, S.O Han, S.W Kim. 2010. Development of batch and continuous processes on biodiesel production in a packed-bed reactor by a mixture of immobilized candida rugose and rhizopus oryzae lipases. Applied Biochemistry and Biotechnology, 161:365-371.

Lenfant, N., T. Hotelier, E. Velluet, Y. Bourne, P. Marchot, A. Chatonnet. 2013. ESTHER, the database of the $\alpha / \beta$-hydrolase fold superfamily of proteins: tools to explore diversity of functions. Nucleic Acids Research, 41 (D1):423-429.

Luna, C., D. Luna, J. Calero, F.M. Bautista, A.A Romero, A. Posadillo, C. Verdugo-Escamilla. 2016. Biochemical catalytic production of biodiesel. Handbook of Biofuels Production, 165-199.

Michael Janda, J., and S.L. Abbott. 2019. 16S rrna gene sequencing for bacterial identification in the diagnostic laboratory: pluses, perils, and pitfalls. Journals of Clinical Microbiology, 45(9).

Mukhtar, S., A. Zaheer, D. Aiysha, K. Malik, S. Mehnaz. 2017. Actinomycetes: a source of industrially important enzymes. Journal of Proteomics and Bioinformatics. 10: 316-319.

Muleta, A., and F. Assefa. 2018. Isolation and screening of antibiotic producing actinomycetes from rhizosphere and agricultural soils. African Journal of Biotechnology, 17(22): 700-714,

Nessner Kavamura, V.,, R.G. Taketani, M.D. Lançoni, F.D. Andreote, R. Mendes, I.S. de Melo. 2013. Water regime influences bulk soil and rhizosphere of cereus jamacaru bacterial communities in the brazilian caatinga biome. PLoS ONE 8(9): e73606.

Nguyen, H.C., S.H. Liang, T.T Doan, C.H. Su, P.C. Yang. 2017. Lipase-catalyzed synthesis of biodiesel from black soldier fly (hermetica illucens): optimization by using response surface methodology. Energy Conversion and Management Elsevier, 145:335-42.

Nuzulia, N.U., Mustofa, J. Widada. Anticancer potential of secondary metabolite of streptomyces sp. GMYo1 on breast cell cancer line T47D dan MCF-7. Thesis. Biotechnology. Universitas Gajah Mada.

Palilingan, S.C. 2013. Optimization of diasilgliserol enzymatic production of CPO by continuously system. [Thesis]. Bogor (ID): Sekolah Pasca Sarjana. Institut Pertanian Bogor.

Ondul, E., N. Dizge, B. Keskinler, and N. Albayrak. 2015. Biocatalytic production of biodiesel from vegetable oils. Biofuels - Status and Perspective. Chapter 2.

Rahayu, Triastuti. 2011. Streptomyces as new source of antibiotic in indonesia. Proceeding Biology Education Conference. 8(1).

Rizwanul Fattah, I.M., H.C. Ong, T.M.I. Mahlia, M. Mofijur, A.S. Silitonga, S.M. Ashrafur Rahman, A. Ahmad. 2020. State of the art of catalysts for biodiesel production. Frontiers in Energy Research. 8: 101.

Saraswati, R., E. Husen, R.D.M. Simanungkali. 2007. Biology soil analysis method. Center for Agricultural Land Resource Research and Development.

Sasso, F., A. Natalello, S. Castoldi S, M. Lotti, C. Santambrogio, R. Grandori. 2016. Burkholderia cepacia lipase is a promising biocatalyst for biofuel production. Biotechnology Journal, 11: 954-960.

Sharma, A., Shadiya, R. Kumar, K. Meena, S.S. Kanwar, T. Sharma. 2019. Biodiesel and the potential role of microbial lipases in its production. p. k. arora (ed.). Microbial Technology for the Welfare of Society. Microorganisms for Sustainability. 17.

Saefulhak, Y., T. Mumpuni, F. Tumiwa. 2017. Renewable energy; energy for now and later. Strategic Parthership for Green and Inclusive Energy. Institute for Essentials Service Reform.

Susilawati, Mustoyo, E. Budhisurya, R.C.W. Anggono, B.H. Simanjuntak. 2013. Analysis of soil fertility with soil microorganism indicator on land use systems in dieng plateau. AGRIC; Journal of Agricultural Science, 25(1): 64-72.

Prakash, D., N. Nawani, M. Prakash, M. Bodas, A. Mandal, M. Khetmalas, B. Kapadnis. 2013. Actinomycetes: A repertory of green catalysts with a potential revenue resource. BioMed Research International, Article ID 264020, 8 pages. 
Tri-Panji, F. Dimawarnita, I. Kresnawaty, S. Saadah, T. Aminingsih, M. Miranti. 2019. Enzymatic glicerolysis of CPO using immobilized lipase for production of diacyl- and monoacyl glycerol. Menara Perkebunan 87(1): 11-19.

Ugur, A., N. Sarac, R. Boran, B. Ayaz, O. Ceylan, G. Okmen. 2014. New lipase for biodiesel production: partial purification and characterization of LipSB 25-4. International Scholarly Research Notices, Article ID 289749, 7 pages, 2014.

Vaijayanthi, G., R. Vijayakumar, D. Dhanasekaran. 2016. Actinobacteria - a biofactory of novel enzymes. Chapter 14. intechopen.49267.

Vargas, M., X. Niehus, L. Casas-Godoy, G. Sandoval. 2018. Lipases as biocatalyst for biodiesel production. Chapter 21. Georgina Sandoval (ed.), Lipases and phospholipases: methods and protocols, methods in molecular biology. vol. 1835,

Wahyuningsih, E. Edy Supriyo, R.T.D. Wisnu Broto, 2015. Biocatalyst lipase rhizopus oryzae in transesterification reactions structured lipids rich in omega-3 fatty acids. METANA: Process Engineering Communication Media and Appropriate Technology, 11(2): 7 - 12.

Wang, X., X. Qin, D. Li, B. Yang, Y. Wang. 2017. One-step synthesis of high-yield biodiesel from waste cooking oils by a novel and highly methanol-tolerant immobilized lipase. Bioresource Technology, 235: 18-24.

Wijayanti, D.R, A. Zulaika, W.F. Safari. 2020. Isolation of actinomycetes with antimicrobial activity from succulent plant rhizosphere. Research Report. Binawan University.

Xiao, M., C. Qi, J.P. Obbard. 2011. Biodiesel production using aspergillus niger as a wholecell biocatalyst in a packed-bed reactor. Bioenergy. 3(4): 293-298.

Yuan, D., D. Lan, R. Xin, B. Yang, Y. Wang. 2016. Screening and characterization of a thermostable lipase from marine Streptomyces sp. strain Woo7. Biotechnology and Applied Biochemistry, 63: 41-50.

Zanane, C., H. Latrache, K. Elfazazi, H. Zahir, M. Ellouali. 2018. Isolation of actinomycetes from different soils of Beni Amir Morocco. Journal of Materials and Environmental Sciences, 2508(10): 2994-3000.

Zheng, L., Y. Hou, W. Li, S. Yang, Q. Li, Z. Yu. 2012. Biodiesel production from rice straw and restaurant waste employing black soldier fly assisted by microbes. Energy, 47: 225-9

Zheng, L., Q. Li, J. Zhang, Z. Yu. 2012. Double the biodiesel yield: rearing black soldier fly larvae, hermetia illucens, on solid residual fraction of restaurant waste after grease extraction for biodiesel production. Renewable Energy 41: 75-9

Zulaika, A., D.R. Wijayanti, W.F. Safari. 2021. A preliminary study of soil microbial abundance in succulent plant rhizospheres. Biota: Biology and Biology Education, 14(1): 14-22 